\title{
Fungal colonisation of outside weathered modified wood
}

\author{
Antje Pfeffer • Patrik J. Hoegger • Ursula Kües • \\ Holger Militz
}

Received: 14 January 2010/Published online: 13 October 2010

(C) The Author(s) 2010. This article is published with open access at Springerlink.com

\begin{abstract}
Specimens of Scots pine sapwood (Pinus sylvestris L.) and beech wood (Fagus sylvatica L.) were treated with an amino-alkyl-functional oligomeric siloxane, a sodium water glass solution and 1,3-dimethylol-4,5-dihydroxyethylene urea (DMDHEU). Treated and untreated wood specimens were exposed outdoors without ground contact. After 9 months of outside exposure, all specimens showed discolouration caused by infestations of mould and staining fungi on the exposed wood surface. Fungi grown on the sample surface were isolated and identified by microscopic technique and sequencing of PCR-amplified DNA from the ITS region. Primarily, an infestation by ascomycetes and related deuteromycetes was found. The most dominant fungi were Trichoderma sp. and Epicoccum sp.. An infestation of Aureobasidium pullulans was only detected on untreated and DMDHEU-treated samples. There were only marginal differences of fungal infestation between the two wood species.
\end{abstract}

\section{Introduction}

Wood is used as material for many outside applications with and without ground contact. Examples for applications without ground contact under use class 3 conditions according to EN 335-1 (2006) are claddings, decking, noise barriers or garden furniture. Decay fungi, moulds and blue stain fungi are able to colonise wood in those applications. Fungal spores are omnipresent in the environment, but the occurrence and amount of spores rely on environmental influences.

\footnotetext{
A. Pfeffer $(\bowtie) \cdot$ H. Militz

Wood Biology and Wood Products, Georg-August-Universität Göttingen, Göttingen, Germany e-mail: apfeffe@gwdg.de 
The process of colonisation depends on the environmental conditions and on the microclimate on the sample surface, which changes permanently during outside exposure. The fungal infestation of wood is a complex process including interactions between fungi, wood and environmental conditions (Deacon 1997). The germination of spores depends on the wood moisture content, temperature, accessible wooden substrate and nutrients (Eaton and Hale 1993; Schmidt 2006). Early colonizers of wood are mainly blue stain and mould fungi (Clubbe 1980; Dix and Webster 1995).

They cause discolouration, but no significant mass loss and generally do not affect the structural properties of wood (Liese and Schmid 1961; Grosser 1985; Zink and Fengel 1988). Free water in the lumens of wood cells over longer periods is needed for the growth of sap-staining fungi.

In the last decades, very effective biocidal treatments were used to protect wood in outside applications. A biocide treatment has a direct impact on the fungal organisms, such as denaturation of proteins, inhibition of protein synthesis or cell membrane disruption (Eaton and Hale 1993). Beside biocide treatment, new wood modification strategies for wood protection have been developed. In comparison with biocidal treatments, these new strategies focus on a change in the material properties of wood to prevent the colonisation by fungi, such as reduction of moisture content and changes in the chemical structure of wood (Hill 2006). Most of the research in chemical modification of wood was done to improve the biological resistance against wood-decaying organisms, while staining reduction was not in the main focus. Fungal colonisation of modified wood particularly in early stages might differ from that of traditionally biocide-treated one, because of a different mode of action against wood-inhabiting organisms. In various studies, identification of fungi from modified and preservative-treated wood was described. In studies by Raberg et al. (2006) on wood panels exposed outdoors at a test field in Uppsala (Sweden), thermally treated Norway spruce specimens were mainly infested by Mucor sp. and Hormonema dematioides and wood panels of acetylated Scots pine sapwood specimens by Cladosporium sp. and Phoma leveillei. Investigations by Choi et al. (2003) in Vancouver (Canada) on copper chromium arsenate (CCA)-treated deckings outside exposed for 0.4-20 years reported an infestation of bacteria, mould and staining fungi, soft rot and basidiomycetes. In this investigation, the most dominant genus was Phialophora sp. Moreover, a relatively low infestation of Trichoderma sp. was observed in this study. Soft rot fungi and basidiomycetes were isolated mostly on the long-term exposed specimens.

Different techniques exist to detect fungal species growing in wood. Morphological identification according to taxonomic guides by cultural characteristics is the traditional way (von Pechmann et al. 1964; Nobles 1965; Wilcox and Dietz 1997). Several molecular methods have been developed in the last years to identify fungi on wood, for example sequence analyses of rDNA regions and fungus-specific amplification of known internal transcribed spacer (ITS) sequences by the polymerase chain reaction (Moreth and Schmidt 2000; Schmidt and Moreth 2002; Hoegger and Kües 2007).

In this study, 1,3-dimethylol-4,5-dihydroxyethylene urea (DMDHEU), an aminoalkyl-functional oligomeric siloxane and a sodium water glass solution were used 
for the chemical modification of pine and beech wood. Previous work indicated that treatments with DMDHEU and siloxanes can restrict but not prevent an infestation of blue stain during outside weathering (Xie 2005; Donath 2004). Water glass treatments resulted after 3 years in above ground weathering tests in lack of infestation by blue stain fungi (Dellith 2006). Little knowledge exists on the type of fungal species that are able to colonise the wood surfaces treated with these chemicals. The objective of this study was therefore to determine the fungal species on the surfaces of modified wood kept for 9 months in outside weathering conditions without ground contact. Morphological characteristics and sequencing of PCR-amplified DNA from the ITS regions of rRNA gene clusters were used for fungal identification.

\section{Materials and methods}

Treatment of the wood specimens

Specimens of Scots pine sapwood (Pinus sylvestris L.) and beech (Fagus sylvatica L.) free of knots and cracks were prepared with a size of $150 \times 74 \times 18 \mathrm{~mm}^{3}$ (longitudinal $\times$ tangential $\times$ radial). The chemicals used in this study for wood modification are described in Table 1.

Impregnation of wood specimens was carried out by applying a vacuum of 60 mbar $(30 \mathrm{~min})$ and a subsequent pressure of 12 bar $(2 \mathrm{~h})$. All treatments were carried out in a laboratory-scale process. After impregnation, siloxane-impregnated specimens were pre-dried at $40^{\circ} \mathrm{C}$ (4day). Curing of the siloxane was subsequently performed at $103^{\circ} \mathrm{C}(24 \mathrm{~h})$.

The water glass-treated specimens were stored for 3 weeks in a desiccator under carbon dioxide atmosphere, which was established by floating the desiccator in regular steps with $\mathrm{CO}_{2}$ from a gas bomb. DMDHEU-impregnated specimens were cured in a hot steam dryer.

\section{Outside exposure}

Prior to outside exposure, specimens of Scots pine sapwood and beech wood were conditioned in a climate chamber at $20^{\circ} \mathrm{C} / 65 \%$ relative humidity (RH). Subsequently, the specimens were placed and fixed on weathering racks with a $45^{\circ}$ slope

Table 1 Chemicals

\begin{tabular}{lll}
\hline Chemical characterisation & Trade name & Concentration \\
\hline Sodium water glass with additives & BETOL 39 T3 (Woellner, & Ludwigshafen, Germany) \\
Amino-alkyl-functional oligomeric siloxane & $\begin{array}{c}\text { DYNASYLAN }{ }^{\circledR} \text { HS 2909 (Evonik, } \\
\text { Rheinfelden, Germany) }\end{array}$ & 20 wt/wt \\
N-methylol compound, 1,3-dimethylol-4,5 & DMDHEU (BASF, Ludwigshafen, \\
dihydroxyethyleneurea (catalyst $\mathrm{MgCl}_{2}$ ) & Germany) & 1.3 M \\
\hline
\end{tabular}


direction towards south-west. The weathering racks were located at a field on the grounds of the University of Goettingen. Ten specimens per treatment and ten untreated specimens were exposed and after 3 months first time inspected for fungal infestations. The surface of each five of them was analysed for fungal infestation on the surface after 9 months (July to March) of outside exposure.

Identification of fungi

Fungi were isolated from the weathered side of the exposed specimens. Parts of the wood specimens that showed visible signs of staining were removed from the surface with sterile tools and placed onto $2 \%$ malt extract agar (MEA, Scharlau Microbiology, Barcelona, Spain) plates. Plates were incubated at $22^{\circ} \mathrm{C}$ and $70 \% \mathrm{RH}$ for several weeks. Fungi growing on MEA were transferred onto fresh MEA plates to obtain pure cultures by further subcultering.

\section{Microscopic analysis}

All plates were observed for macroscopic characteristics such as colour of mycelia, colour of mycelium, colour of the reverse side of the mycelium and growth rate of fungal culture. Microscopic characteristics, such as hyphal features and spore properties (size, shape, colour), were observed on slides using an Eclipse E 600 light microscope (Nikon Germany, Düsseldorf, Germany). For fungal identification, taxonomic guides were used (Funder 1953; Arx von 1981; Larone 1995; Watanabe 2002; Dugan 2006). The microscopic analysis was performed with stained (lactophenol blue) and unstained species of the fungal culture.

\section{PCR analyses}

ITS sequence characterisation was used for fungal identification. The DNA was extracted from fungal mycelium as described in rapid DNA mini preparation protocol by Liu et al. (2000). PCR was performed in a total volume of $25 \mu \mathrm{l}$ containing $10 \mathrm{mM}$ Tris $\mathrm{pH} 8.8,50 \mathrm{mM} \mathrm{KCl}, 0.1 \%$ Triton $\mathrm{X}-100,1.5 \mathrm{mM} \mathrm{MgCl} 2$, $0.2 \mathrm{mM}$ dNTPs (Fermentas, St. Leon-Rot, Germany), each $0.4 \mu \mathrm{M}$ of primer and 1 U of Taq DNA polymerase. The standard primers for ITS amplification in fungi (ITS1 5'-TCCGTAGGTGAACCTGCGG-3' and ITS4 5'-TCCTCCGCTTATTGATATGC- $3^{\prime}$ ) (White et al. 1990) were used. PCR conditions were 2-min initial denaturation at $94^{\circ} \mathrm{C}$, followed by 35 cycles of $30 \mathrm{~s}$ at $94^{\circ} \mathrm{C}, 30 \mathrm{~s}$ at $55^{\circ} \mathrm{C}$ and $30 \mathrm{~s}$ at $72^{\circ} \mathrm{C}$ and a final extension at $72^{\circ} \mathrm{C}$ for $10 \mathrm{~min}$. For sequencing, PCR products were precipitated with $35 \mu \mathrm{l}$ isopropanol, dried and resuspended in $20 \mu \mathrm{l} \mathrm{H} 2 \mathrm{O}$. For cycle sequencing reactions, $2 \mu \mathrm{l}$ of the DNA were mixed with BigDye Terminator v3.1 (Applied Biosystems, Darmstadt, Germany) applying one-fourth of the reagents recommended by the manufacturer. The same primers as for PCR were separately used in sequencing reactions. After cycling following the manufacturer's instructions, the reaction products were purified by sodium acetate/ethanol precipitation and washed with $70 \%$ ethanol. The reaction was run on an ABI PRISM 3,100 Genetic Analyzer (Applied Biosystems). The obtained sequences 
from the different fungal mycelia were assembled by using the STADEN PACKAGE program and searched in the NCBI GenBank using the BLAST search function. Obtained sequences were recorded at NCBI under accession numbers GU433218 to GU 433226.

\section{Results and discussion}

\section{Outside exposure}

All chemical treatments restricted the fungal infestation at the beginning of outside exposure (3 months) compared to untreated specimens. However, all specimens showed visible surface discolouration after 9-month outside exposure caused by a fungal infestation of mould and stain on the exposed wood surface. The untreated specimens of Scots pine sapwood displayed the highest surface discolouration and the water glass-treated samples of Scots pine sapwood the lowest discolouration. Signs of fungal decay were not visible on treated and untreated wood specimens.

A radial penetration of fungal hyphae was reduced, but fungal growth of the exposed surface of the specimens was clearly visible. However, the fungal penetration into the wood tissue is different between treated and untreated wood. DMDHEU treatment of wood reduced the penetration depth of fungi such as Aureobasidium pullulans into wood and siloxane as well as water glass treatment fully blocked the invasion (Xie et al. 2008; Pfeffer et al. 2010). Moisture gradients exist in wood from the outer to the inner zones (Eaton and Hale 1993). In the DMDHEU- and siloxane-treated samples, the moisture content of the exposed surfaces might be lower because of the presence of chemicals on the surface as well as in the main penetration paths for liquid water, which block the transfer of water into the inner zones of the wood (Donath et al. 2006, 2007; Xie et al. 2008) and, consequently, restricts the growth of fungi.

\section{Identification of fungi}

After 9 months of outside exposure, fungal mycelia were isolated from all specimens of Scots pine and beech wood by using agar medium. Pure cultures of morphological distinct isolates were incubated for 6-8 weeks required for some of the isolates for efficient sporulation. Five of the analysed fungi could not be classified by lack of spores. Hyphae and mitospore characteristics were used to identify the other isolates by microscopic characteristics, such as exemplary shown in Fig. 1 for conidia of Lewia sp. and Fig. 2 for macroconidia of Fusarium sp.

The sporulating fungi were found to belong to seven different genera of the ascomycetes and related deuteromycetes (fungi imperfecti). Only one isolate (A. pullulans) was identified at the species level (see Tables 2 and 3).

There were only marginal differences of fungal infestation between the two wood species. The most dominant fungi in this study were Trichoderma sp. and Epicoccum sp..Trichoderma sp. was isolated from all test specimens independent of treatment and wood species. An infestation of A. pullulans was only detected on 


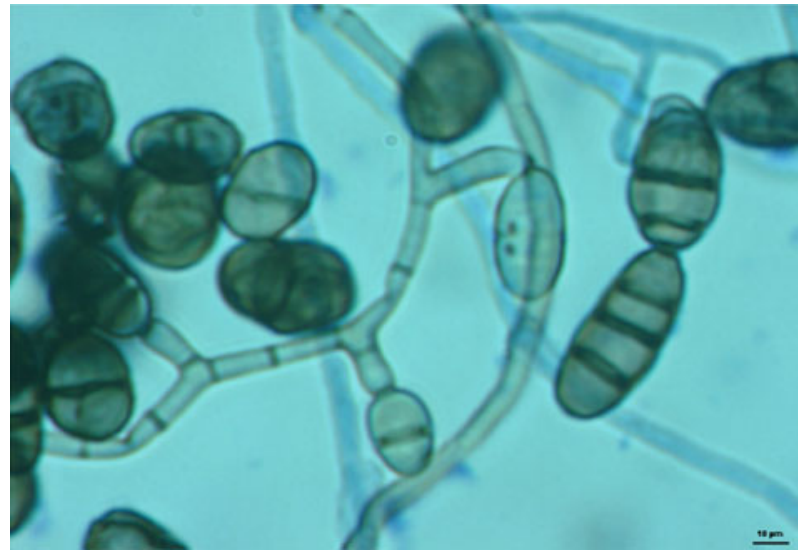

Fig. 1 Conidia of Lewia sp., 400×

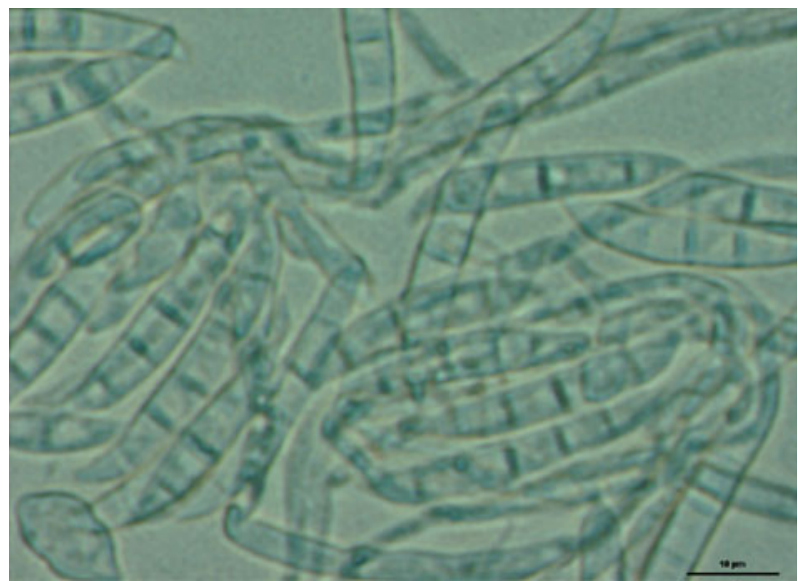

Fig. 2 Macroconidia of Fusarium sp., 1.000×

untreated and DMDHEU-treated specimens. Other fungi occurred irregularly on wood specimens without a recognisable preference for wood type or treatment of wood (see Table 4).

In the following, fungal isolates taken from Scots pine specimens were selected for molecular identification. In all instances, ITS sequences obtained from the fungi enabled the identification of a fungal genus. The molecular identification confirmed the genera identification of the microscopic observations.

BLAST searches in the NCBI database showed that the sequences of the isolates had a homology of minimal $90 \%$ with the best matching sequences. By sequence hits, five fungi including A. pullulans could be identified at the species level. Furthermore, the formerly not definable isolates were determined by ITS sequences as Peniophora sp., Hypocrea sp. and Diplodia sp., respectively. 
Table 2 Fungi isolated from Scots pine sapwood specimens and identified by microscopic analysis

$x$ Fungus isolated

Table 3 Fungi isolated from beech specimens and identified by microscopic analysis

$x$ Fungus isolated

\begin{tabular}{llllll}
\hline No. & Fungal identity & \multicolumn{2}{l}{ Treatment } & & \\
\cline { 3 - 5 } & & Untreated & Siloxane & $\begin{array}{l}\text { Water } \\
\text { glass }\end{array}$ & DMDHEU \\
\hline 1 & Trichoderma sp. & $\mathrm{x}$ & $\mathrm{x}$ & $\mathrm{x}$ & $\mathrm{x}$ \\
2 & Epicoccum $\mathrm{sp}$. & $\mathrm{x}$ & $\mathrm{x}$ & $\mathrm{x}$ & $\mathrm{x}$ \\
3 & Aureobasidium & $\mathrm{x}$ & & & $\mathrm{x}$ \\
4 & pullulans & & & & \\
5 & Cewia $\mathrm{sp}$. & & & $\mathrm{x}$ & \\
6 & Fusartomium $\mathrm{sp}$. & & & $\mathrm{x}$ & \\
7 & Unknown & $\mathrm{x}$ & & $\mathrm{x}$ & \\
8 & Unknown & & & $\mathrm{x}$ & \\
9 & Unknown & & $\mathrm{x}$ & & \\
\hline
\end{tabular}

\begin{tabular}{llllll}
\hline No. & Fungal identity & \multicolumn{2}{l}{ Treatment } & & \\
\cline { 3 - 5 } & & Untreated & Siloxane & $\begin{array}{l}\text { Water } \\
\text { glass }\end{array}$ & DMDHEU \\
\hline 1 & Trichoderma $\mathrm{sp}$. & $\mathrm{x}$ & $\mathrm{x}$ & $\mathrm{x}$ & $\mathrm{x}$ \\
2 & Epicoccum $\mathrm{sp}$. & & $\mathrm{x}$ & $\mathrm{x}$ & \\
3 & Aureobasidium & $\mathrm{x}$ & & & $\mathrm{x}$ \\
4 & pullulans & & & & \\
5 & Lewia sp. & & & $\mathrm{x}$ & \\
6 & Chaetomium $\mathrm{sp}$. & $\mathrm{x}$ & & & \\
7 & Penicillium $\mathrm{sp}$. & $\mathrm{x}$ & & & \\
8 & Unknown & & & $\mathrm{x}$ & \\
\hline
\end{tabular}

Table 4 Fungi isolated from Scots pine and identified by ITS sequence analysis

\begin{tabular}{lllllc}
\hline No. & $\begin{array}{l}\text { GenBank } \\
\text { accession }\end{array}$ & $\begin{array}{l}\text { GenBank } \\
\text { best hit }\end{array}$ & Fungal identity & $\begin{array}{l}\text { Sequence } \\
\text { identity (\%) }\end{array}$ & $\begin{array}{l}\text { Query coverage } \\
\text { of sequence (\%) }\end{array}$ \\
\hline 1 & GU433218 & AJ 279448 & Epicoccum nigrum & 99 & 100 \\
2 & GU433219 & AY 853249 & Aureobasidium pullulans & 97 & 97 \\
3 & GU433220 & AF 456917 & Trichoderma atroviride & 100 & 99 \\
4 & GU433221 & AF 397240 & Lewia infectoria & 100 & 95 \\
5 & GU433222 & EF 524036 & Chaetomium globosum & 100 & 99 \\
6 & GU433223 & FJ 614630 & Fusarium sp. & 100 & 100 \\
7 & GU433224 & AY 208796 & Peniophora sp. & 97 & 98 \\
8 & GU433225 & FJ 442679 & Hypocrea sp. & 95 & 100 \\
9 & GU433226 & EU 650671 & Diplodia sp. & 98 & 90 \\
\hline
\end{tabular}


In summary, a collection of 10 different species of ascomycetes and related deuteromycetes was isolated from chemically modified Scots pine sapwood and beech wood specimens as well as untreated samples after 9-month outside exposure. All fungi detected in this study are ubiquitary and have previously been reported as mould and stain fungi on exposed surfaces of treated and untreated wood species at different climatic conditions (Choi et al. 2003; Raberg et al. 2006, 2007; Cabrera et al. 2009). Clubbe (1980) stated that bacteria, primary moulds and staining fungi are the initial colonists in untreated Scots pine, substituted in time first by soft rots and then basidiomycetes and cellulolytic secondary moulds. Other authors differentiated infestation by primary moulds in the beginning, followed by infestation of staining and soft rot fungi and then secondary moulds and in the latest stage infestation by wood-degrading basidiomycetes (Käärik 1983; Dix and Webster 1995; Deacon 2006). According to these schemes, the fungal infestation of this study corresponds to the initial stage where mould and stain fungi are the main colonizers.

The composition of fungal species on outside-exposed wood specimens is influenced by the material itself and the type of treatment it had, by climatic influences (surrounding temperature, relative humidity, rainfall) and exposure time and the influence of the general local environment on the microbial biodiversity (Käärik 1983; Eaton and Hale 1993).

On wood, interactions between fungal species have also a strong impact on the composition of fungal infestation (Dix and Webster 1995). The most dominant fungus Trichoderma atroviride in this study is a mycoparasitic species that may grow necrotrophically on diverse fungi on wood and bark and act in biocontrol of sapstain species (Schubert et al. 2008). Epicoccum nigrum, the second most often found species in this study, has also antogonistic properties against the growth of other fungi (Madrigal et al. 1994), and related species have been shown to delay wood decay by xylophagus basidiomycetes (Mielnichuk and Lopez 2007). It is therefore possible that these two fungi restricted the growth of other species during outside exposure of the wood specimens of this study.

However, well-known technical problems during isolation may result in a biased spectrum of isolates which cannot be fully excluded in this study. For instance, slow-growing mycelium can be easily overgrown during the isolation steps by more rapidly growing mycelia. Trichoderma atroviride on the one hand is capable of very fast growth (Jaklitsch 2009) whereas on the other hand, Aureobasidium pullulans is only growing at a slower rate (Butin 1964). Likewise, fast-growing non-decay fungi can overgrow slower wood basidiomycete decay fungi (Dix and Webster 1995). Basidiomycete decay fungi were not isolated in this study, not even from untreated wood specimens, either due to such technical deficiencies or because such late fungi in wood infestation were not yet present in the wood.

Further investigations after longer periods of outside exposure will be necessary to get more detailed information about the changes of fungal species and schemes of fungal infestations on siloxane-, water glass- and DMDHEU-treated wood in comparison with untreated wood. 


\section{Conclusion}

Wood specimens treated with a sodium water glass solution, a siloxane and DMDHEU showed after 9-month outside exposure a surface discolouration caused by mould and staining fungi while there were no signs of decay. All fungi detected in this study on wood surfaces are ubiquitary and have previously been reported on exposed wood surfaces. There were only marginal differences of species distribution between the two wood species. But the fungal distribution and penetration into the wood were different between treated and untreated wood. A. pullulans that typically causes blue stain in service on outside-exposed wooden surfaces was only detected on untreated and DMDHEU-treated specimens, but the fungal penetration into the wood tissue was strongly reduced in DMDHEU-treated specimens. Basidiomycetes decay fungi were not isolated in this study.

Acknowledgments We thank the "Deutsche Bundesstiftung Umwelt" (DBU) for granting Antje Pfeffer a doctoral scholarship and for funding the chair Molecular Wood Biotechnology at the Faculty of Forest Sciences and Forest Ecology at the Georg-August-University Göttingen. The BMBF (Bundesministerium für Bildung und Forschung) supported a database project on fungal ITS sequences (grant 0330551 to UK).

Open Access This article is distributed under the terms of the Creative Commons Attribution Noncommercial License which permits any noncommercial use, distribution, and reproduction in any medium, provided the original author(s) and source are credited.

\section{References}

Arx von JA (1981) The genera of fungi sporulating in pure culture. Cramer, Vaduz

Butin H (1964) Untersuchungen zur Ökologie einiger Bläuepilze an verarbeitetem Kiefernholz. Flora 155:400-440

Cabrera Y, Freitag C, Morrell JJ (2009) Effect of preservative treatment on fungal colonization of Teak, Redwood, and Western Red Cedar. Document No.: IRG/WP 09-20404. International Research Group on Wood Protection, Stockholm

Choi SM, Ruddick JNR, Morris PI (2003) Fungal colonization of CCA-treated decking. Document No.: IRG/WP 03-10491. International Research Group on Wood Protection, Stockholm

Clubbe CP (1980) The colonisation and succession of fungi in wood. Document No.: IRG/WP 1107. International Research Group on Wood Preservation, Stockholm

Deacon JW (1997) Modern mycology. Blackwell Publishing, Oxford

Deacon JW (2006) Fungal biology. Blackwell Publishing, Oxford

Dellith W (2006) Beitrag zum alternativen Holzschutz durch modifizierte Alkalisilikatlösungen als Schutzmittel gegenüber holzzerstörenden Pilzen und Insekten. Dissertation, Bauhaus-Universität Weimar, Fakultät für Bauingenieurwesen

Dix NJ, Webster J (1995) Fungal ecology. Chapman and Hall, London

Donath S (2004) Treatment of wood with silanes. PhD-thesis. University of Göttingen, Institute of Wood Biology and Wood Technology

Donath S, Militz H, Mai C (2006) Creating water-repellent effects on wood by treatment with silanes. Holzforschung 60:40-46

Donath S, Militz H, Mai C (2007) Weathering of silane treated wood. Holz Roh- Werkst 65:35-42

Dugan FM (2006) The identification of fungi. Am Phytopathol Soc, St. Paul

Eaton RA, Hale MDC (1993) Wood-Decay, pests and protection. Chapman \& Hall, London

EN 335-1 (2006) Durability of wood and wood based products. Definition of use classes-Part 1: General

Funder S (1953) Practical mycology: manual for identification of fungi. Broggers Boktr. Torlag, Oslo

Grosser D (1985) Pflanzliche und tierische Bau- und Werkholzschädlinge. DRW-Verlag, LeinfeldenEchterdingen 
Hill CAS (2006) Wood modification: chemical, thermal and other processes. John Wiley \& Sons Ltd, Chichester

Hoegger P, Kües U (2007) Molecular detection of fungi in wood. In: Kües U (ed) Wood Production. Wood technology and Biotechnological Impacts, Universitätsverlag Göttingen, Göttingen

Jaklitsch WM (2009) European species of Hypocrea. Part 1: The green-spored species. Stud Mycol 63:1-91

Käärik A (1983) Decomposition of wood. In: Dickinson CH, Pugh GJF (eds) Biology of plant litter decomposition, Academic press, New York

Larone DH (1995) Medically important fungi - A guide to identification, 3rd edn. ASM Press, Washington D.C

Liese W, Schmid R (1961) Licht- und elektronenmikroskopische Untersuchungen über das Wachstum von Bläuepilzen in Kiefern- und Fichtenholz. Holz Roh- Werkst 19:329-337

Liu D, Coloe S, Baird R, Pedersen R (2000) Rapid mini-preparation of fungal DNA for PCR. J Clin Microbiol 38(1):471

Madrigal C, Pascual S, Melgarejo P (1994) Biological control of peach twig blight (monilinia-laxa) with Epicoccum nigrum. Plant Pathol 43:554-561

Mielnichuk N, Lopez SE (2007) Interactions between Epicoccum purpurascens and xylophagous basidiomycetes on wood blocks. For Pathol 37:236-242

Moreth U, Schmidt O (2000) Identification of indoor rot fungi by taxon-specific priming polymerase chain reaction. Holzforschung 54:1-8

Nobles MK (1965) Identification of cultures of wood inhabiting Hymenomycetes. Can J Bot 43:1097-1139

Pfeffer A, Mai C, Militz H (2010) Weathering characteristics of water glass, siloxane and DMDHEU treated wood. Submitted in Europ J Wood and Wood Prod

Raberg U, Bijelovic J, Land CJ, Bardage S, Terziev N (2006) Identification of fungi colonising coated and modified wood exposed outdoors using sequencing and T-RFLP profiling. Document No.: IRG/ WP 06-20326. International Research Group on Wood Protection, Stockholm

Raberg U, Brischke C, Rapp AO, Högberg NOS, Land CJ (2007) External and internal fungal flora of pine sapwood (Pinus sylvestris L.) specimens in above-ground field tests at six different sites in south-west Germany. Holzforschung 61:104-111

Schmidt O (2006) Wood and tree fungi. Springer Verlag, Berlin

Schmidt O, Moreth U (2002) Data bank of rDNA-ITS sequences from building-rot fungi for their identification. Wood Sci Technol 36:429-433

Schubert M, Fink S, Schwarze FWMR (2008) Evaluation of Trichoderma spp. as a biocontrol agent against wood decay fungi in urban trees. Biol Control 45:111-123

von Pechmann H, Graessle E, Wutz A (1964) Untersuchungen über Bläuepilze an Kiefernholz. Forstwiss Centralblatt 83:290-314

Watanabe T (2002) Pictorial atlas of soil and seed fungi: morphologies of cultured fungi and key to species. CRC press, Boca Raton

White TJ, Bruns T, Lee S, Taylor JW (1990) Amplification and direct sequencing of fungal ribosomal RNA genes for phylogenetics. In: Innis MA, Gelfand DH, Sninsky JJ, White TJ (eds) PCR protocols: a guide to methods and applications. Academic press, New York

Wilcox WW, Dietz M (1997) Fungi causing above-ground wood decay in structures in California. Wood and Fiber Science 29:291-298

Xie Y (2005) Surface properties of wood modified with cyclic N-methylol compounds. PhD-thesis. University of Göttingen, Institute of Wood Biology and Wood Technology

Xie Y, Krause A, Militz H, Mai C (2008) Weathering of uncoated and coated wood treated with methylated 1, 3-dimethylol-4, 5-dihydroxyethyleneurea (mDMDHEU). Holz Roh Werkst 66:455-464

Zink P, Fengel D (1988) Studies on the colouring matter of blue-stain fungi, Part 1. General characterisation and the associated compounds. Holzforschung 42:217-220 